\title{
Preliminary study on heavy metal concentrations of Anatolian Khramulya, Capoeta tinca (Heckel, 1843) from Çamlıgöze Dam Lake, Sivas, Turkey
}

\author{
Seher Dirican ${ }^{1 *}$, Süleyman Çilek ${ }^{2}$, Hakan Çiftçi ${ }^{3}$, Mutluhan Bıyıkoğlư ${ }^{4}$, Servet Karaçınar ${ }^{5}$ and Ahmet Yokuş ${ }^{5}$
}

\begin{abstract}
The concentrations of heavy metals ( $\mathrm{Ag}, \mathrm{Cd}, \mathrm{Co}, \mathrm{Cu}, \mathrm{Ni}, \mathrm{Pb}, \mathrm{Zn}$ ) were analyzed in muscle, skin and liver of Anatolian Khramulya, Capoeta tinca (Heckel, 1843) from Çamlıgöze Dam Lake located at Central Anatolian region of Turkey. The heavy metal analysis of samples was carried out by using a flame atomic absorption spectrophotometer. Ag, $\mathrm{Cd}, \mathrm{Co}, \mathrm{Pb}$ and $\mathrm{Zn}$ were found in all of the examined tissues. $\mathrm{Cu}$ and $\mathrm{Ni}$ were not determined in all tissues studied. The mean concentrations of heavy metals in all of the examined tissues of Capoeta tinca were as follows: Ag: $0.057 \pm 0.038-0.120 \pm 0.051, C d: 0.020 \pm 0.004-1.451 \pm 0.879$, Co: $0.127 \pm 0.067-0.205 \pm 0.086$, Pb: $1.939 \pm 0.477-$ $2.604 \pm 0.393$ and Zn: $0.056 \pm 0.014-0.530 \pm 0.129 \mu \mathrm{g} / \mathrm{g}$ in Çamlıgöze Dam Lake. According to international criterias and Turkish regulation, heavy metal concentrations especially $\mathrm{Cd}$ and $\mathrm{Pb}$ in Çamlıgöze Dam Lake were found above the permissible levels for examined tissues of Capoeta tinca. Furthermore, frequent consumption of contaminated fish is able to offer a serious public health risk. Therefore, the concentrations of metals accumulated in the fish, which are commonly consumed by public, should be monitored periodically in Çamlıgöze Dam Lake.
\end{abstract}

Keywords: Capoeta tinca, Çamlıgöze dam lake, Heavy metal, Sivas

\section{Introduction}

Heavy metals are natural trace components of the aquatic environment, but their levels have increased due to industrial wastes, geochemical structure, agricultural and mining activities. All these sources of pollution affect the physiochemical characteristics of the water, sediment and biological components, and thus the quality and quantity of fish stocks [1-3]. In recent years, and based on the importance of fish as a part of a healthy diet, there has been a notable promotion of fish consumption. Fish is an important source of food for humans. The nutritional benefits of fish are mainly due to the content of high-quality protein, vitamins and other essential nutrients. Moreover, unlike fatty meat products, fish are not high in saturated fat. Also it has been advised that fish should be consumed two or three times weekly, because of the pharmaceutical effects of

\footnotetext{
*Correspondence: sdirican48@gmail.com

'Department of Fisheries, Suşehri Vocational Training School, Cumhuriyet University, Suşehri, Sivas, Turkey

Full list of author information is available at the end of the article
}

omega three polyunsaturated fatty acids, which exist abundantly in fish oil [4-6].

Anatolian Khramulya, Capoeta tinca (Heckel, 1843) is a species of the family Cyprinidae and has a wide distribution in western Asia. Capoeta tinca has a wide distribution in North and Northwest Anatolia of Turkey and lives in systems that are hydrologically connected to the Black Sea. Capoeta tinca can adapt very easily to changes in water regime, it occurs both in lotic and lentic habitats so this species has economic value as a commercial fish from natural and man-made lakes. Becuase of its delicious flesh, people perfer this fish species to consume as food and it is so important commercially in Turkey [7-12]. To date, heavy metals in Capoeta tinca from Çamlıgöze Dam Lake has not been directly studied. For Çamlıgöze Dam Lake, heavy metals in Capoeta tinca are given for the first time. The aim of this study was carried out to investigate accumulation of heavy metals $(\mathrm{Ag}, \mathrm{Cd}$, $\mathrm{Co}, \mathrm{Cu}, \mathrm{Ni}, \mathrm{Pb}, \mathrm{Zn}$ ) in muscle, skin and liver tissues of Anatolian Khramulya, Capoeta tinca (Heckel, 1843) from 
Çamlıgöze Dam Lake located at Central Anatolian region of Turkey.

\section{Materials and methods Study area}

Çamlıgöze Dam Lake is located at Central Anatolian region of Turkey (Figure 1). Geographical cordinates of Çamlıgöze Dam Lake are $40^{\circ} 13^{\prime} 45^{\prime \prime} \mathrm{N}, 38^{\circ} 04^{\prime} 36^{\prime \prime} \mathrm{E}$ ). The province of Sivas is located at the eastern part of the Central Anatolian region of Turkey. Çamlıgöze Dam Lake is situated approximately $140 \mathrm{~km}$ north-east of Sivas province centre. The Çamlıgöze Dam was constructed between 1987 and 1998 on the Kelkit Stream, a tributary of Yeşilırmak River. Çamlıgöze Dam is a $37 \mathrm{~m}$ high rockfill a power plant. The water of Çamlıgöze Dam Lake is mainly used for produce electrical energy, aquaculture, commercial fishing, irrigation, and recreation. The surface area and maximum depth of the Çamlıgöze Dam Lake are $5 \mathrm{~km}^{2}$ and $30 \mathrm{~m}$ respectively. Average capacity of Çamlıgöze Dam Hydroelectric Station is 102 GWh/year [13,14].

\section{Sampling and sample preparation}

Fish samples were caught with nets of various mesh sizes $(40-60 \mathrm{~mm})$ between 11 January 2011 and 28 March 2011. Eleven specimens of Capoeta tinca were caught from Çamlıgöze Dam Lake. Fish samples were transferred to the laboratory to record age, sex, total body length and total wet weight. Body weight and total length of each individuals were measured with a precision of $0.1 \mathrm{~g}$ and $0.1 \mathrm{~cm}$. Fish samples were washed with water, packed in polyethylene bags and stored at $-20^{\circ} \mathrm{C}$ until analysis. Scales taking from under dorsal fin were used for age determination. For this purpose, scales were kept in $3 \% \mathrm{NaOH}$ solution for 24 hours, and than washed in distilled water and treated with $70 \%$ alcohol solution [15]. After cleaning the scales were examined under a steromicroscope to allow age for determination. Sexual characteristics in this species were determined on gonadal tissues naked eye or using a microscope. Males differ from females morphologically by the presence of breeding tubercules formed on the head during the spawning period. Approximatelly 1 or $2 \mathrm{~g}$ of the muscle,



Figure 1 Çamlıgöze Dam Lake. skin and liver samples were dissected from 11 fish specimens. Soft tissues were extracted from each fish samples using a plastic knife. After they were individually transferred to $20 \mathrm{~mL}$ glass vials previously washed with $0.1 \mathrm{~N}$ nitric acid, dried, and weighed, they were dried in an oven for 24 hours at $105^{\circ} \mathrm{C}$ and kept in an oven. Then samples were kept at room temperature for 24 hours by adding $3 \mathrm{~mL}$ nitric acid. Then samples can withstand heat very low heats on a hot metal plate have been mineralized until the color disappears slowly heated vapors. Then the samples were added to $1 \mathrm{~mL}$ sulfuric acid. The samples were added into the 1-2 drops of nitric acid. The digested samples were diluted to $50 \mathrm{~mL}$ with distilled water $[16,17]$. The solution was transferred and filtered through $0.45 \mu \mathrm{m}$ nitrocellulose membrane filter and ready for analysis [18].

Standard solutions for calibration graphs were prepared from stock solutions. All chemicals used for experiments and analyses were of analytical grades. Stock solutions of $1000 \mathrm{mg} / \mathrm{L} \mathrm{Cu}$ (II), Ag (I), Co (II), Ni (II), $\mathrm{Cd}$ (II), Pb (II) and $\mathrm{Zn}$ (II) were supplied by Merck Company and used without further purification. Standard solutions for each metal ion were prepared from stock solutions in $25 \mathrm{~mL}$ flasks. Calibration graph for each batch of experiments were re-constructed by using the standard solutions. Analysis of the heavy metals in the fish samples were carried out using a flame atomic absorption spectrophotometer (GBC model 932AA) to determine the concentrations of cadmium $(\mathrm{Cd})$, cobalt $(\mathrm{Co})$, copper $(\mathrm{Cu})$, lead $(\mathrm{Pb})$, nickel $(\mathrm{Ni})$, silver $(\mathrm{Ag})$ and zinc $(\mathrm{Zn})$. The concentrations of heavy metals were expressed as $\mu \mathrm{g} / \mathrm{g}$ (wet weight). The absorption wavelength were as follows: $328.100 \mathrm{~nm}$ for Ag; $228.802 \mathrm{~nm}$ for $\mathrm{Cd}$; $228.616 \mathrm{~nm}$ for $\mathrm{Co} ; 327.393 \mathrm{~nm}$ for $\mathrm{Cu} ; 231.604$ $\mathrm{nm}$ for $\mathrm{Ni}$; $217.000 \mathrm{~nm}$ for $\mathrm{Pb}$ and $213.900 \mathrm{~nm}$ for $\mathrm{Zn}$. The detection limits were $0.1-11 \mu \mathrm{g} / \mathrm{g}$ for Ag; $0.2-1.8$ $\mu \mathrm{g} / \mathrm{g}$ for $\mathrm{Cd}$; $0.1-9 \mu \mathrm{g} / \mathrm{g}$ for $\mathrm{Co} ; 1-5 \mu \mathrm{g} / \mathrm{g}$ for $\mathrm{Cu}$; $0.2-0.8$ $\mu \mathrm{g} / \mathrm{g}$ for $\mathrm{Ni} ; 1.5-20 \mu \mathrm{g} / \mathrm{g}$ for $\mathrm{Pb}$ and $0.2-1.5 \mu \mathrm{g} / \mathrm{g}$ for $\mathrm{Zn}$.

\section{Statistical analysis}

One way analysis of variance was performed with Minitab 13.0 statistical package program on the data obtained in this study. Important differences in the mean values were tested with Duncan's multiple range test.

\section{Results}

A total of eleven specimens of Anatolian Khramulya, Capoeta tinca were caught from study area. The specimens were examined consisted 10 females and 1 male. The ages of the captured specimens of Anatolian Khramulya (Capoeta tinca) ranged from 5 to 9 years and the 8rd group was dominant in the population. The total length of the Anatolian Khramulya population in Çamlıgöze Dam Lake ranged from $31.3 \mathrm{~cm}$ to $47.7 \mathrm{~cm}$. 
Weights of the Anatolian Khramulya ranged between $405.2 \mathrm{~g}$ and $1335.7 \mathrm{~g}$. The mean total length of all Anatolian Khramulya samples was determined $41.081 \pm$ $1.329 \mathrm{~cm}$. The mean weight of all Anatolian Khramulya samples was determined $966.463 \pm 82.867 \mathrm{~g}$ in Çamlıgöze Dam Lake. Some morphometric and biological characteristics of fish samples (minimum, maximum, mean and standard error) are given in Table 1.

The mean concentrations of heavy metals in muscle, skin and liver of Anatolian Khramulya, Capoeta tinca are summarized in Table 2. Ag, Cd, Co, Pb and $\mathrm{Zn}$ were detected in all of the examined tissues. $\mathrm{Cu}$ and $\mathrm{Ni}$ were not detected in all of the examined tissues. The mean heavy metal concentrations were determined in muscle as follows; Ag: $0.120 \pm 0.051 \mu \mathrm{g} / \mathrm{g}$, Cd: $0.218 \pm 0.203 \mu \mathrm{g} / \mathrm{g}$, Co: $0.135 \pm 0.073 \mu \mathrm{g} / \mathrm{g}, \mathrm{Pb}: 2.604 \pm 0.393 \mu \mathrm{g} / \mathrm{g}$ and $\mathrm{Zn}: 0.056 \pm$ $0.014 \mu \mathrm{g} / \mathrm{g}$. The mean heavy metal concentrations were determined in skin as follows; Ag: $0.111 \pm 0.047 \mu \mathrm{g} / \mathrm{g}, \mathrm{Cd}$ : $0.020 \pm 0.004 \mu \mathrm{g} / \mathrm{g}$, Co: $0.205 \pm 0.086 \mu \mathrm{g} / \mathrm{g}, \mathrm{Pb}: 2.373 \pm$ $0.373 \mu \mathrm{g} / \mathrm{g}$ and $\mathrm{Zn}: 0.530 \pm 0.129 \mu \mathrm{g} / \mathrm{g}$. The mean heavy metal concentrations were determined in liver as follows; Ag: $0.057 \pm 0.038 \mu \mathrm{g} / \mathrm{g}, \mathrm{Cd}: 1.451 \pm 0.879 \mu \mathrm{g} / \mathrm{g}$, Co: $0.127 \pm 0.067 \mu \mathrm{g} / \mathrm{g}, \mathrm{Pb}: 1.939 \pm 0.477 \mu \mathrm{g} / \mathrm{g}$ and $\mathrm{Zn}$ : $0.289 \pm 0.036 \mu \mathrm{g} / \mathrm{g}$. The highest concentrations were found in muscle ( $\mathrm{Pb}: 2.604 \pm 0.393 \mu \mathrm{g} / \mathrm{g}$ and $\mathrm{Cd}$ : $0.218 \pm 0.203 \mu \mathrm{g} / \mathrm{g}$ ), in skin (Pb: $2.373 \pm 0.373 \mu \mathrm{g} / \mathrm{g}$ and $\mathrm{Zn}: 0.530 \pm 0.129 \mu \mathrm{g} / \mathrm{g}$ ) and in liver (Pb: $1.939 \pm 0.477$ $\mu \mathrm{g} / \mathrm{g}$ and Cd: $1.451 \pm 0.879 \mu \mathrm{g} / \mathrm{g})$ of Capoeta tinca from Çamlıgöze Dam Lake (Table 2). Mean concentrations in the muscle, skin and liver of Capoeta tinca were found as follows: $\mathrm{Pb}>\mathrm{Cd}>\mathrm{Co}>\mathrm{Zn}>\mathrm{Ag} ; \mathrm{Pb}>\mathrm{Zn}>\mathrm{Co}>$ $\mathrm{Ag}>\mathrm{Cd} ; \mathrm{Pb}>\mathrm{Cd}>\mathrm{Zn}>\mathrm{Co}>\mathrm{Ag}$. The distribution patterns of $\mathrm{Ag}$ and $\mathrm{Pb}$ in tissues of Capoeta tinca follows the order: muscle $>$ skin $>$ liver; Cd follows the order: liver $>$ muscle > skin; Co follows the order: skin $>$ muscle $>$ liver and $\mathrm{Zn}$ follows order: skin $>$ liver $>$ muscle.

The mean concentration of $\mathrm{Ag}$ in muscle, skin and liver, was $0.120 \pm 0.051 ; 0.111 \pm 0.047$; and $0.057 \pm 0.038$ $\mu \mathrm{g} / \mathrm{g}$. The data showed that, muscle accumulated the highest concentration while liver accumulated the lowest. The mean Cd concentrations were $0.218 \pm 0.203 \mu \mathrm{g} /$ $\mathrm{g}$ in muscle, $0.020 \pm 0.004 \mu \mathrm{g} / \mathrm{g}$ in skin and $1.451 \pm 0.879$ $\mu \mathrm{g} / \mathrm{g}$ in liver. The data revealed that, liver accumulated the highest concentration of $\mathrm{Cd}$ while skin accumulated the lowest concentration. The mean Co concentrations were $0.135 \pm 0.073 \mu \mathrm{g} / \mathrm{g}$ in muscle, $0.205 \pm 0.086 \mu \mathrm{g} / \mathrm{g}$ in skin and $0.127 \pm 0.067 \mu \mathrm{g} / \mathrm{g}$ in liver. The data revealed that, skin accumulated the highest concentration of Co while liver accumulated the lowest concentration. The mean $\mathrm{Pb}$ concentrations were $2.604 \pm 0.393 \mu \mathrm{g} / \mathrm{g}$ in muscle, $2.373 \pm 0.373 \mu \mathrm{g} / \mathrm{g}$ in skin and $1.939 \pm$ $0.477 \mu \mathrm{g} / \mathrm{g}$ in liver. The data revealed that, muscle accumulated the highest concentration of $\mathrm{Pb}$ while liver accumulated the lowest concentration. The mean $\mathrm{Zn}$ concentrations were $0.056 \pm 0.014 \mu \mathrm{g} / \mathrm{g}$ in muscle, $0.530 \pm 0.129 \mu \mathrm{g} / \mathrm{g}$ in skin and $0.289 \pm 0.036 \mu \mathrm{g} / \mathrm{g}$ in liver. The data revealed that, skin accumulated the highest concentration of $\mathrm{Zn}$ while muscle accumulated the lowest concentration (Table 2).

The significance levels of heavy metal accumulation in the tissues were defined with Duncan's multiple range test. Letters a, b and c showed differences among tissues. There are important statistical differences, especially at the level of $\mathrm{Zn}$ accumulation in tissues $(\mathrm{P}<0.001)$. The highest accumulation of $\mathrm{Zn}$ was observed in skin (with $0.530 \pm 0.427 \mu \mathrm{g} / \mathrm{g}$ ) while the lowest accumulation of $\mathrm{Zn}$ was observed in muscle (with $0.056 \pm 0.049 \mu \mathrm{g} / \mathrm{g}$ ). There are no statistical differences, among the concentrations of $\mathrm{Ag}, \mathrm{Cd}, \mathrm{Co}$ and $\mathrm{Pb}$ in tissues $(\mathrm{P}>0.05)$. According to the results of analysis derived through atomic absorption spectrometry, it is confirmed that heavy metals accumulate in different tissues. The highest Ag concentration was observed in muscle of Capoeta tinca $(0.120 \pm 0.051 \mu \mathrm{g} / \mathrm{g})$, while the lowest $(0.057 \pm 0.038 \mu \mathrm{g} / \mathrm{g})$ was in liver. The highest $\mathrm{Cd}$ concentration was observed in muscle of Capoeta tinca $(1.451 \pm 0.879 \mu \mathrm{g} / \mathrm{g})$, while the lowest $(0.020 \pm 0.004 \mu \mathrm{g} / \mathrm{g})$ was in skin. The highest Co concentration was observed in skin of Capoeta tinca $(0.205 \pm$ $0.086 \mu \mathrm{g} / \mathrm{g})$, while the lowest $(0.127 \pm 0.067 \mu \mathrm{g} / \mathrm{g})$ was in liver. The highest $\mathrm{Pb}$ concentration was observed in liver of Capoeta tinca $(2.604 \pm 0.393 \mu \mathrm{g} / \mathrm{g})$, while the lowest $(1.939 \pm 0.477 \mu \mathrm{g} / \mathrm{g})$ was in liver. The highest $\mathrm{Zn}$ concentration was observed in skin of Capoeta tinca $(0.530 \pm$ $0.129 \mu \mathrm{g} / \mathrm{g})$, while the lowest $(0.056 \pm 0.014 \mu \mathrm{g} / \mathrm{g})$ was in muscle (Table 2).

\section{Discussion}

There are various studies on the heavy metal levels in Capoeta tinca from different freshwater ecosystems in Turkey [19-24]. The mean $\mathrm{Cd}, \mathrm{Pb}$ and $\mathrm{Zn}$ values in muscle and liver of Capoeta tinca obtained in this study were lower than those obtained by Ağcasulu [20] in

Table 1 Some morphometric and biological characteristics of Capoeta tinca

\begin{tabular}{|c|c|c|c|c|c|}
\hline \multirow[t]{4}{*}{ Species } & $\mathrm{N}$ & F/M & Age & Total length $(\mathrm{cm})$ & Weight (g) \\
\hline & & & Min.-Max. & Min.-Max. & Min.-Max. \\
\hline & & & Mean $\pm \mathrm{SE}$ & Mean \pm SE & Mean \pm SE \\
\hline & & & $5-9$ & $31.3-47.7$ & $405.2-1335.7$ \\
\hline Capoeta tinca & 11 & $10 q / 10$ & $7.636 \pm 0.387$ & $41.081 \pm 1.329$ & $966.463 \pm 82.867$ \\
\hline
\end{tabular}


Table 2 Mean heavy metals concentrations in different tissues of Capoeta tinca $(\mu \mathrm{g} / \mathrm{g})$

\begin{tabular}{cccccc}
\hline & Ag & Cd & Co & Pb & Zn \\
Tissues & Mean \pm SE & Mean \pm SE & Mean \pm SE & Mean \pm SE & Mean \pm SE \\
\hline Muscle & $0.120 \pm 0.051$ & $0.218 \pm 0.203$ & $0.135 \pm 0.073$ & $2.604 \pm 0.393$ & $0.056 \pm 0.014 \mathrm{C}$ \\
Skin & $0.111 \pm 0.047$ & $0.020 \pm 0.004$ & $0.205 \pm 0.086$ & $2.373 \pm 0.373$ & $0.530 \pm 0.129 \mathrm{a}$ \\
Liver & $0.057 \pm 0.038$ & $1.451 \pm 0.879$ & $0.127 \pm 0.067$ & $1.939 \pm 0.477$ & $0.289 \pm 0.036 \mathrm{~b}$ \\
$\mathbf{P}$ & 0.577 & 0.127 & 0.730 & 0.527 & $0.001^{*}$ \\
\hline
\end{tabular}

The asteriks notation $(*: P<0.001 ; P>0.05)$ shows the significance level in the Table.

Capoeta tinca from Çeltikçe Stream. Similarly, the mean $\mathrm{Cd}$ and $\mathrm{Zn}$ values in muscle of Capoeta tinca obtained in this study were lower than those obtained by Mendil et al. [19] in Capoeta tinca from Yeşilırmak River. The mean $\mathrm{Zn}$ values in all of the examined tissues of Capoeta tinca obtained in this study were lower than those obtained by Mendil and Uluözlü [22] in Capoeta tinca from Bedirkale Dam Lake and Ataköy Dam Lake. The mean $\mathrm{Zn}$ values in all of the examined tissues of Capoeta tinca obtained in this study were lower than those obtained by Mendil et al. [23] in Capoeta tinca from Yeşilırmak River. The mean Cd values in muscle and liver of Capoeta tinca obtained in this study were lower than those obtained by Canberk et al. [21] in Capoeta tinca from Porsuk River. The mean $\mathrm{Cd}$ values in muscle of Capoeta tinca obtained in this study were lower than those obtained by Akbulut and Tuncer [24] in Capoeta tinca from Kizllırmak River Basin. The mean $\mathrm{Pb}$ values in muscle of Capoeta tinca obtained in this study were higher than those obtained by Mendil et al. [19] in Capoeta tinca from Yeșilırmak River. The mean $\mathrm{Pb}$ values in all of the examined tissues of Capoeta tinca obtained in this study were higher than those obtained by Mendil and Uluözlü [22] in Capoeta tinca from Ataköy Dam Lake. The mean $\mathrm{Pb}$ values in all of the examined tissues of Capoeta tinca obtained in this study were lower than those obtained by Mendil and Uluözlü [22] in Capoeta tinca from Bedirkale Dam Lake. The mean $\mathrm{Pb}$ values in muscle and liver of Capoeta tinca obtained in this study were higher than those obtained by Canberk et al. [21] in Capoeta tinca from Porsuk River. Mean Cd concentrations ranged from $0.020 \pm$ $0.004 \mu \mathrm{g} / \mathrm{g}$ to $1.451 \pm 0.879 \mu \mathrm{g} / \mathrm{g}$ in all of the examined tissues of Capoeta tinca in Çamlıgöze Dam Lake. These values are similar to those reported previously $[19,23]$.

A number of metal ions are essential for biological systems as $\mathrm{Na}, \mathrm{K}, \mathrm{Ca}, \mathrm{Mn}, \mathrm{Fe}, \mathrm{Co}, \mathrm{Cu}, \mathrm{Mo}$ and $\mathrm{Zn}$. Small quantities of B, Si, V, As, Se, Ni, Nb, Rb, Sr, and Ti were found essential for living organism. Some other metals are non essential such as $\mathrm{Cd}, \mathrm{Pb}, \mathrm{Hg}[25,26]$. The heavy metals are the most important forms of pollution and they may accumulate in the tissues of fish which are often at the top of the aquatic food chain. They are accumulated in human tissues and may be the cause of some diseases fish may concentrate large amounts of metals from the water and they might be toxic for human consumption [27-30]. Among the different metals analyzed, $\mathrm{Pb}$ and $\mathrm{Cd}$ are classified as toxic metals, which causes chemical hazards and therefore maximum residual levels have been prescribed for human consumption by various agencies of food standards [31-33]. $\mathrm{Pb}$ and $\mathrm{Cd}$ are biologically non essential metals which are acumulated in human tissues and harmful to human health [34].

The permissible limits proposed by the FAO, WHO and Turkish legislation established the following maximum levels for the metals studied, above which consumption is not permitted: $0.1 \mu \mathrm{g} / \mathrm{g}$ for $\mathrm{Cd}, 5 \mu \mathrm{g} / \mathrm{g}$ for $\mathrm{Cu}, 50 \mu \mathrm{g} / \mathrm{g}$ for $\mathrm{Zn}$ and $0.5 \mu \mathrm{g} / \mathrm{g}$ or $1 \mu \mathrm{g} / \mathrm{g}$ for $\mathrm{Pb}$ [35-37]. According to international criterias and Turkish regulation, heavy metal concentrations especially $\mathrm{Cd}$ and $\mathrm{Pb}$ in Çamlıgöze Dam Lake were found above the permissible levels for examined tissues of Capoeta tinca. However the concentrations of $\mathrm{Zn}(0.056 \pm 0.014 \mu \mathrm{g} / \mathrm{g}$ in muscle; $0.530 \pm 0.129 \mu \mathrm{g} / \mathrm{g}$ in skin; $0.289 \pm 0.036 \mu \mathrm{g} / \mathrm{g}$ in liver) was determined lower than the acceptable limits. $\mathrm{Cu}$ was not detected in all of the examined tissues of Capoeta tinca. There is also legislation in other countries regulating the maximum concentration of metals. For example, Spanish legislation limits the levels for $\mathrm{Cd}$ at $1 \mu \mathrm{g} / \mathrm{g}, \mathrm{Cu}$ at $20 \mu \mathrm{g} / \mathrm{g}$ and $\mathrm{Pb}$ at $2 \mu \mathrm{g} / \mathrm{g}[38,39]$. According to Spanish legislation limits, heavy metal concentrations $\mathrm{Pb}$ in Çamlıgöze Dam Lake were a bit above the permissible levels for edible tissues of Capoeta tinca. Heavy metal concentration $\mathrm{Cd}$ was above the permissible levels in liver. A comparison with the European Community food standards [32], for fish Cd: 0.05-0.10 $\mu \mathrm{g} / \mathrm{g}$ and Pb: $0.2-0.4 \mu \mathrm{g} / \mathrm{g}$. According to European Community food standards, heavy metal concentrations $\mathrm{Cd}$ and $\mathrm{Pb}$ in Çamlıgöze Dam Lake were found above the permissible levels for examined tissues of Capoeta tinca.

\section{Conclusion}

The results obtained from this study will provide information for the background levels of metals in common fish species of the lake. To the best of our knowledge, the heavy metal concentrations of Anatolian Khramulya, Capoeta tinca are presented in Çamlıgöze Dam Lake for 
the first time in this study. Our results showed that the concentrations of $\mathrm{Cd}$ and $\mathrm{Pb}$ detected in tissues of Anatolian Khramulya, Capoeta tinca from Camlıgöze Dam Lake were found above the FAO, WHO, ITS and EC maximum permissible limits.

\section{Competing interests}

The authors declare that no conflict of interest.

\section{Authors' contributions}

All authors contributed to the manuscript. All persons listed as authors have read, contributed to preparing the manuscript and attest to the validity and legitimacy of the data and its interpretation, and agree to its submission to "Iranian Journal of Environmental Health Science \& Engineering". No person more than the authors listed have contributed significantly to its preparation. All authors read and approved the final manuscript.

\section{Acknowledgements}

We thank to Bülent Demircan for his help in the field work

\section{Author details}

'Department of Fisheries, Suşehri Vocational Training School, Cumhuriyet University, Suşehri, Sivas, Turkey. ${ }^{2}$ Department of Animal Breeding, Faculty of Veterinary Medicine, Kırıkkale University, Yahşihan, Kırıkkale, Turkey. ${ }^{3}$ Department of Chemistry and Chemical Processing Technologies, Kırıkkale Vocational Training School, Kırıkkale University, Yahşihan, Kırıkkale, Turkey. ${ }^{4}$ Department of Chemistry, Faculty of Art and Sciences, Kırıkkale University, Yahşihan, Kırıkkale, Turkey. ${ }^{5}$ Department of Food Technology, Suşehri Vocational Training School, Cumhuriyet University, Suşehri, Sivas, Turkey.

Received: 26 June 2012 Accepted: 01 June 2013

Published: 13 June 2013

\section{References}

1. Zyadah MA: Accumulation of some heavy metals in Tilapia zillii organs from Lake Manzalah, Egypt. Turk J Zool 1999, 23:365-372.

2. Kalay M, Canlı M: Elimination of essential $(\mathrm{Cu}, \mathrm{Zn})$ and non-essential $(\mathrm{Cd}, \mathrm{Pb})$ metals from tissues of a freshwater fish Tilapia zillii following an uptake protocol. Turk J Zool 2000, 24:429-436.

3. Tekin-Özan S: Determination of heavy metal levels in water, sediment and tissues of tench (Tinca tinca L., 1758) from Beyşehir Lake (Turkey). Environ Monit Assess 2008, 145:295-302.

4. Hu FB, Cho E, Rexrode KM, Albert CM, Manson JE: Fish and long-chain omega-3 fatty acid intake and risk of coronary heart disease and total mortality in diabetic women. Circul 2003, 107:1852-1857.

5. Domingo JL, Bocio A, Falco G, Llobet JM: Benefits and risks of fish consumption part I a quantitative analysis of the intake of omega-3 fatty acids and chemical contaminants. Toxicol 2007, 230:219-226.

6. Uysal K, Köse E, Bülbül M, Dönmez M, Erdoğan Y, Koyun M, Ömeroğlu Ç, Özmal F: The comparison of heavy metal accumulation ratios of some fish species in Enne Dam Lake (Kütahya/Turkey). Environ Monit Assess 2009, 157:355-362.

7. Erk'akan F: The fishes of Thrace region. Hacettepe Bull Nat Sci Eng 1983, 12:39-48.

8. Geldiay R, Balık S: Freshwater fishes in Turkey, Volume 16. Izmir, Turkey: Ege Univ. Fisheries Faculty, Publication; 1996:532.

9. Yıldirım A, Aras MS: Some reproduction characteristics of Capoeta tinca (Heckel, 1843) living in the Oltu Stream of Çoruh Basin. Turk J Zool 2000 24:95-101.

10. Ekmekçi FG, Özeren SC: Reproductive biology of Capoeta tinca in Gelingüllü Reservoir. Turkey Folia Zool 2003, 52(3):323-328.

11. Yilmaz S, Polat N: Length-weight relations of Anatolian Khramulya, Capoeta tinca (Actinopterygii: Cypriniformes: Cyprinidae), from Samsun Province, Northern Turkey. Acta Ichthy Et 2009, 39(1):39-41.

12. Alaş A: Reproductive biology of Capoeta tinca inhabiting Kayaboğazı Dam Lake (North-West Anatolia, Turkey). Kafkas Univ Vet Fak Derg 2010, 16:179-182.

13. Aydogar Si: Work of the provincial districts of Suşehri in Turkey. İstanbul, Turkey: [in Turkish], Acar Printing Company; 2004:160.
14. Dirican S, Musul H, Çilek S: Some physico-chemical characteristics and rotifers of Çamlıgöze Dam Lake, Suşehri, Sivas. Turkey J Anim Vet Adv 2009, 8(4):715-719.

15. Lagler KF: Freshwater fishery biology. lowa: WMC Brown Company; 1966:412

16. Calta M, Canpolat O, Nacar A: Determining the level of some heavy metals of Capoeta trutta (Heckel, 1843) caught in Elazığ Keban Dam Lake. Erzurum, Turkey: Eastern Anatolia Region IV. Symposium of Fisheries; 2000:799-811.

17. Çalta M, Canpolat Ö: The comparison of three Cyprinid species in terms of heavy metals accumulation in some tissues. Water Environ Res 2006, 78(5):548-551.

18. Alam MGM, Tanaka A, Allinson G, Laurenson LJB, Stagnitti F, Snow E: A comparison of trace element concentrations in cultured and wild carp (Cyprinus carpio) of Lake Kasumigaura, Japan. Ecotoxic Environ Safety 2002, 53:348-354.

19. Mendil D, Tüzen M, Sarı H, Suiçmez M, Hasdemir E: Trace metal levels in tissues of fish (Capoeta tinca) from the River Yeşilırmak in Tokat. Turkey Fres Environ Bull 2005, 14(10):960-965

20. Agcasulu O: Investigation of accumulation of heavy metals in tissues of Capoeta tinca (Heckel, 1843) living in Çeltikçe Stream of Sakarya River. Ankara, Turkey: in Turkish], Gazi Univ, Institute of Science and Technology, M.Sc. Thesis; 2007:43.

21. Canberk M, Demir TA, Uyanoğlu M, Bayramoğlu G, Emiroğlu Ö, Arslan N, Koyuncu O: Preliminary assessment of heavy metals in water and some Cyprinidae species from the Porsuk River. Turkey J Appl Biol Sci 2007, 1(3):91-95.

22. Mendil D, Uluözlü ÖD: Determination of trace metal levels in sediment and five fish species from lakes in Tokat, Turkey. Food Chem 2007, 101:739-745.

23. Mendil D, Ünal ÖF, Tüzen M, Soylak M: Determination of trace metals in different fish species and sediments from the River Yeşilırmak in Tokat, Turkey. Food Chem Toxicol 2010, 48:1383-1392.

24. Akbulut NE, Tuncer AM: Accumulation of heavy metals with water quality parameters in Kızılırmak River Basin (Delice River) in Turkey. Environ Monit Assess 2011, 173:387-395.

25. Johansen P, Mulvad HS, Pedersen G, Hansen JC, Riget F: Accumulation of cadmium in livers and kidneys in Greenlanders. Sci Tot Environ 2006 372(1):58-63.

26. Ferreira AP: Trace metals concentration in Fregata magnificens: A case study of Coroa Grande Mangrove in Sepetiba Bay, Rio de Janeiro. Brazil J Oceanog Mar Sci 2011, 2(2):43-49.

27. Rodriguez VM, Jimenez-Capdeville ME, Giordano M: The effects of arsenic exposure on the nervous system. Toxicol Lett 2003, 145(1):1-18.

28. Papagiannis I, Kagalou I, Leonardos J, Petridis D, Kalfakakou V: Copper and zinc in four freshwater fish Species from Lake Pamvotis (Greece). Environ Int 2004, 30:357-362.

29. Yılmaz F, Özdemir N, Demirak A, Tuna AL: Heavy metal levels in two fish species Leuciscus cephalus and Lepomis gibbosus. Food Chem 2007 100(2):830-835.

30. Oymak SA, Karadede-Akın H, Doğan N: Heavy metal in tissues of Tor grypus from Atatürk Dam Lake, Euphrates River-Turkey. Biologia 2009, 64(1):151-155.

31. FAO: Compilation of legal limits for hazardous substances in fish and fishery products. No: 464th edition. Food and Agriculture Organisation (FAO) Fishery Circular: Food and Agriculture Organisation (FAO) Fishery Circular; 1983:5-100

32. EC: European Community, Commission regulation as regards heavy metals. Directive 2001:

33. Rejomon $\mathrm{G}$, Nair M, Joseph $\mathrm{T}$ : Trace metal dynamics in fishes from the southwest coast of India. Environ Monit Assess 2010, 1(4):243-255. 167.

34. Indrajith HAP, Pathiratne KAS, Pathiratne A: Heavy metal levels in two food fish speceis from Negombo estuary, Sri Lanka: Relationships with the body size. Sri Lanka J Aquat Sci 2008, 13:63-81.

35. FAO/WHO: Evaluation of certain food additives and contaminants mercury, lead and cadmium, WHO Technical Report Series, Volume 505. : 1989.

36. WHO: World Health Organization, Forty-first Report of the Join Expert Committee on Food Additives (JEFCA), Technical Report Series, Volume 837. No: 837th edition. ; 1993:53

37. ITS: Institute of Turkish Standards for Food. The Ministry of the Agriculture of Turkey; 2000. Report 5. 
38. Usero J, Izquierdo C, Morillo J, Gracia I: Heavy metals in fish (Solea vulgaris, Anguilla anguilla and Liza aurata) from salt marshes on the southern Atlantic Coast of Spain. Environ Int 2003, 1069:1-8.

39. Demirak A, Yllmaz F, Tuna AL, Özdemir N: Heavy metals in water, sediment and tissues of Leuciscus cephalus from a stream in southwestern Turkey. Chemos 2006, 63:1451-1458.

doi:10.1186/2052-336X-11-7

Cite this article as: Dirican et al:: Preliminary study on heavy metal concentrations of Anatolian Khramulya, Capoeta tinca (Heckel, 1843)

from Çamlıgöze Dam Lake, Sivas, Turkey. Journal of Environmental Health Science and Engineering 2013 11:7.

\section{Submit your next manuscript to BioMed Central and take full advantage of:}

- Convenient online submission

- Thorough peer review

- No space constraints or color figure charges

- Immediate publication on acceptance

- Inclusion in PubMed, CAS, Scopus and Google Scholar

- Research which is freely available for redistribution 